\title{
Research on Training Mode of Accounting Personnel in the Demand of Professional Competence
}

\author{
Yinghong Zhao ${ }^{1, a}$ and Danmeng $\mathrm{Gao}^{2, \mathrm{~b}}$
}

${ }^{1}$ College of International Business, Shenyang Normal University, 110023, Shenyang, Liaoning, P.R. China

${ }^{2}$ Business School, Liaoning University, 110023, Shenyang, Liaoning, P.R. China

aZhaoyinghong2005@126.com, b247771785@qq.com

Keywords: Professional competence; Demand; Accounting personnel; Training mode; The objective of accounting training

\begin{abstract}
From the needs of accounting professional competence perspective, we discussed the need of accounting reflect object for what kind of professional competence accounting personnel should have and analyzed what kind of professional competence accounting personnel should have in the present market demand. Aiming at issues of training mode for accounting personnel, we used questionnaire analysis method and analyzed the situation of training for accounting personnel in some of colleges and universities in Liaoning Province. We came up with the objective of accounting training and innovate the reform path such as teaching model so that we could provide reference for the reform of training mode for accounting personnel in Chinese universities.
\end{abstract}

\section{职业能力需求下会计人才培养模式研究 赵迎红 ${ }^{1, a}$, 高丹梦2,b \\ 1. 沈阳师范大学 国际商学院，中国 辽宁 沈阳 110023 \\ 2. 辽宁大学 商学院，中国 辽宁 沈阳 110023 \\ a'Zhaoyinghong2005@126.com, b247771785@qq.com}

摘要: 从会计的职业能力需求角度出发, 探讨了会计反映对象对会计人才应具备的职业能力 的需求, 分析了市场需求下会计人才应具备的职业能力, 针对会计人才培养模式问题, 采用 问卷调查分析的方法, 分析了辽宁省部分高校会计人才培养情况, 提出了会计人才培养目标、 创新教学模式等改革路径，以期为我国高校本科会计人才培养模式的改革提供借鉴。

\section{关键词：职业能力；需求；会计人才；培养模式；培养目标}

\section{1. 引言}

随着市场经济的发展，会计在企业经营管理、会计信息服务和管理决策中将发挥着越来越大 的作用 $[1-3]$ 。会计人员是否能够及时、有效地提供会计信息，是对会计人员综合素质的一种 检验, 检验会计人员综合素质的唯一标准是会计信息使用者对会计人员的满意程度 [4-5]。因 此, 作为向社会培养和输送会计人才的会计高等本科教育, 将再一次面临进一步进行深层次 教学改革的问题 [6-8]。如对学生培养目标的定位、课程体系的设计、学生培养的质量、适应 市场需求情况等问题。

\section{2. 市场需求下会计人才应具备的职业能力}

根据我们对企业的走访了解到, 能适应新经济环境的会计人员除需要掌握会计基础知识、管 理学基础、经济学基础知识外, 还需要具有良好的职业道德、沟通能力、人际交往能力、会 
计职业判断能力以及解决各种异常问题的能力。目前, 企业对不同层次会计人员的职业技能 要求是不同的。

2.1. 一般会计人员的职业能力需求

企业一般会计人员应当具备会计核算和账务处理、编制企业财务报表、银行相关业务处理、 日常发票的开具以及纳税申报等具体执行方面的职业能力，对于企业的筹资、投资等经营策 略方面的职业能力要求则较低。其主要原因是一般会计人员主要负责具体办理财务收支业务, 主要完成会计核算的基本职能。

2.2. 会计主管人员的职业能力需求

会计主管人员不仅要具备会计核算和账务处理、编制企业财务报表、银行相关业务处理等基 础性的职业能力, 还要求具备税务管理与纳税筹划、财务预算、投资管理等企业管理方面的 职业能力。

2.3. 高级会计人员的职业能力需求

高级会计人员不仅仅掌管好企业日常财务工作、管理财务部门、控制财务风险, 还需要了解企 业经营的全过程，与企业外部的投资者、债权人建立良好的关系，协调企业内部各职能部门 的工作，为企业的短期经营决策、筹资决策以及长期投资决策等重大事项提供相关信息。因 此, 高级会计人员必须在财务方面具有优秀的专业技能, 具备对企业战略的财务分析能力和 资本运作、长期成本管理等能力。

由此我们看到, 如何根据市场对不同会计人员的职业能力需求来改革当前高校的会计课程体 系，将影响着高校所培养的会计人才职业竞争能力和发展前途。

\section{3. 辽宁省高校会计人才培养现状调查与分析}

本课题组对辽宁省不同层次的高校14级、15级两届会计本科毕业生进行了问卷调查。共发放 调查问卷248份, 收回225份, 回收率 $90.73 \%$; 有效问卷 205 份, 有效率 $91.11 \%$ 。针对企业发放 了150份调查问卷，收回134份，回收率 $89.33 \%$; 有效问卷 121 份, 有效率 $90.30 \%$ 。根据调查结 果具体分析如下:

3. 1. 会计人才培养目标不符合市场需求

从发放企业收回的问卷调查结果显示， $26.5 \%$ 的用人单位选择了综合型人才， $23.8 \%$ 的用人单 位选择了应用型人才，用人单位选择注册会计师的占 $7.2 \%$ 。对会计专业毕业生的问卷调查结 果显示, $80 \%$ 以上的学生希望会计专业人才类型为综合型和应用型, 仅有 $2.5 \%$ 的学生希望成 为注册会计师及创新型人才。因此, 会计人才培养目标不能完全适应会计市场环境需求的变 化。

3. 2. 会计职业能力的培养不做重要程度区分

问卷调查结果显示，超过 50\%的学生认为，用人单位对会计工作的基本知识、分析会计信息 与资料、会计实践操作能力和应变能力的要求最高。而高校在人才培养时忽略了综合素质的 培养，对会计职业能力的培养也没有按重要程度予以区分。

3. 3. 会计课程设置没有考虑实用性

对“已学课程对会计工作重要程度”的调查结果显示: $60 \%$ 以上的学生认为非常重要的课程是 基础会计、中级财务会计、成本会计、财务管理、管理会计、电算化会计、高级财务会计和 财务分析等课程。在教材的选用上，50\%以上同学认为目前我国高校的会计课程教材有相当 一部分内容比较陈旧, 缺乏实践性、内容不够接近实际工作, 导致刚刚步入工作岗位时所学 与所用有较大的差距。还有一部分同学认为, 选用国外的教材, 学校的目的是要引进和借鉴 国外原版教材，拉近我们与世界一流大学差距，但其结果是更加偏离中国的现实国情。

\section{4. 缺乏实践能力}

在 “应当注重会计人才哪些职业能力的培养” 的调查中，普遍反映应着重培养学生会计实践 能力和综合素质；大部分院校已经建立了财务会计模拟实验室、ERP实验室等各种实验室， 但仍然存在不能与社会需求同步更新的问题。在对企业 “毕业生实际工作能力” 的调查结果 
显示: $50 \%$ 以上的企业认为, 毕业生的实践能力较差, 实际动手能力不强。由此反映出我们 的会计模拟实验室, 没有满足培养出完全胜任企业会计工作职业能力需求。

3. 5. 教学模式缺乏创新

在 “你喜欢什么样的教学模式” 的调查中, $60 \%$ 以上的学生喜欢探究式教学、案例教学模式; 比例最低的是传递一接受式的学习模式。可见在新的教学改革中, 不但要注重教学课程体系 的安排, 还需要重视教学模式的改革与创新, 以适应新的经济环境对会计人才职业能力的需 求。

\section{4. 高校本科会计人才培养改革的建议}

4.1. 缩小会计培养目标与职业能力需求之间的缺口

随着我国社会经济的发展和我国会计改革的不断推进, 各类经济组织的经营环境和会计环境 日益复杂, 会计职业的服务范围也越来越广泛。会计服务范围的扩大势必引起会计职业能力 需求的变化, 需要具有掌握更多职业技能的综合型应用人才, 以适应社会经济环境的不断变 革对会计职业能力提出的新要求。

4.2. 课程体系的设计适应职业能力的需求

会计课程体系的设计必须服从职业能力的需求, 贯彻人才培养过程中的创新思想, 突破原有 传统会计专业学科的既有思路, 适应会计人才参与企业战略制定和实施的职业能力需求。社 会经济环境不是固定的, 因此, 职业能力需求也不是固定的, 只有目标是确定的, 即为企业 创造价值, 提高会计职业贡献, 在会计学科建设、人才培养中, 注重会计职业的通用能力的 训练。

4.3. 改革教学方式和教学手段

推行适应当前与未来经济发展和市场需求的新型会计教学模式, 不断提高会计教师实践能力, 培养会计教师的社会责任感, 改进教师的实践教学水平, 建立、健全和完善合理有效的教师 激励与约束考评机制, 使会计课程体系的改革效果真正得以实现。

4. 4 . 创新教学模式

创新教学模式是要完善会计人才创新能力培养的内容及要求, 针对会计专业的实用性特点, 进行会计基本技能竞赛、会计实务操作职业技能竞赛等; 在会计教学过程中, 多采用案例教 学、情景教学、模拟训练, 以提高学生对所学专业知识的综合应用能力。

4.5. 搭建多元化教学平台 加强高校会计院系与企业、政府的交流合作[9-10], 通过为企业提供专业咨询与培训、会计专 业教师在企业或会计师事务所兼职、开展会计人员继续教育培训等服务, 将企业的高级会计 人员、注册会计师以及政府财政部门、审计部门、税务部门等把握最新政策和实际操作能力 的人员引进校园, 形成会计人才培养联盟体, 这样, 才能实现人才专业培养与职业能力需求 的有效对接。

\section{5. 结论}

本文运用调查分析的方法, 对辽宁省不同层次高校会计专业人才培养情况以及社会对会计专 业人才的职业能力需求进行了分析, 提出了高校本科会计人才培养模式改革的建议。

\section{6. 致谢}

感谢辽宁省教育规划项目课题立项, 课题编号: JG14DB390。 


\section{参考文献}

[1] 杨政, 殷俊明, 宋雅琴. 会计人才能力需求与本科会计教育改革: 利益相关者的调查分析 [J].会计研究，2012，(1): 25-35.

[2] 章新蓉，顾飞.开放式会计人才培养模式创新与实践研究 [J].会计之友，2012，(12下): 117-119.

[3] 刘玲雪.信息化背景下我国本科会计人才培养模式研究一一基于利益相关者的调查分析 [D].硕士，内蒙古工业大学，中国，2015,38-52.

[4] 易玄, 刘冬荣.环境变迁、需求变化以及大学会计教育改革一一来自我国大学的实证 $[\mathrm{J}]$. 湖南科技大学学报( 社会科学版), 2012, （7）：156-160.

[5] 陈春华.高校会计国际化课程体系研究——基于国内10 所高校的调查分析[J].财会通讯, 2013，(6上)：31-33.

[6] 田月昕，王艳.职业能力框架下高校会计职业规划[J].商场现代化，2012，（1）：37-38.

[7] 会计行业中长期人才发展规划（2010－2020）[J].会计研究，2010，（10）：89-94.

[8] 何玉润, 李晓慧.我国高校会计人才培养模式研究一一基于美国十所高校会计学教育的实 地调研 $[J]$.会计研究，2013，（1）：26-31.

[9] 刘淑花, 陈英.基于市场需求的国际化会计人才培养模式的构建 $[\mathrm{J}]$. 经济师，2012，（9）: 100-102.

[10]王京芳.会计人才培养模式改进的路径选择——基于职业能力的需求与协同效应 $[\mathrm{J}]$.大学 教育，2013，（1）：75-78.

\section{Acknowledgement}

This research was financially supported by Liaoning economic and Liaoning provincial education plan project (JG14DB390)

\section{References}

[1] Barbara Apostolou.Accounting Education Literature Review(2006 -2009) [J], Journal of Accounting Education.2010,(28) : 145-197.

[2] Mohamed EKA.Accounting Knowledge and Skills and Challenges of a Global Business Environment[J]. Managerial Finance.2003,29(7) : 3-16.

[3] ZhengYang,JunmingYin,YaqinSong.Accounting talent ability and accounting university education reform:Investigation of stakeholders[J].Accounting Research,2012,(1):25-35.

[4] XuanYi,DongrongLiu.The change of the environment ,the variety of the demand and university Accounting Education Reform - Evidence from the Chinese University[J].Journal of Hunan University of Science and Technology,2012,(7):156-161.

[5] LifangJi.Reform of maket demand-oriented undergraduate accounting talents training model[J].Journal of Liaoning Technical University(Social science edition),2013,(1):107-109.

[6] Yuexin,Tian,Yan Wang.Accounting career planning under the framework of professional competence. [J].Market Modernization,2012,(1):37-38.

[7] Long-term talent development plan in accounting industry(2010-2020) [J].Accounting Research,2010,(10):89-94. 
[8] Yurun He,Xiaohui Li.Research on training mode of college accounting-Based on field research of ten universities in accounting education in US[J]. Accounting Research,2013,(1):26-31.

[9] Shuhua Liu,Ying Chen.Construction based on international accounting personnel training model in market demand[J].Magazine official website,2012,(9):100-102.

[10] Jingfang Wang.Path selection of the improving of accounting training mode-Based on the demand and synergy of professional competence. [J].University Education,2013,(1):75-78.

作者简介：赵迎红（1966）, 女, 辽宁法库, 副教授, 实证会计理论及微观经济统计, zhaoyinghong2005@126.com。 